\title{
Financial Feasibility Analysis of NAABB Developed Technologies
}

\author{
James W. Richardson ${ }^{*}$ and Myriah D. Johnson ${ }^{1}$
}

${ }^{1}$ Agricultural \& Food Policy Center, Department of Agricultural Economics, Texas A\&M University, College Station, TX 77843, USA

*Correspondence:

James Richardson (jwrichardson@tamu.edu) 


\begin{abstract}
In 2010, the National Alliance for Biofuels and Bioproducts (NAABB), was tasked with developing innovative technologies that would make algae-based biofuels a sustainable, commercially viable industry. Over the past few years an array of technologies have been developed and analyzed. Each of these was detailed in the final report to the United States Department of Energy. In this paper, the most promising technologies developed in NAABB are compared to the baseline technologies from the beginning of the project. An economic feasibility analysis is conducted using the Farm-level Algae Risk Model (FARM) to simulate the probabilistic cost of algal lipid production and the economic feasibility for the farms with the most promising alternative technologies. This economic feasibility analysis is a high level analysis of technologies that need to be demonstrated seamlessly at full scale and are yet to be fully integrated into a single operation with full mass and energy balance. Technologies analyzed include: a genetically modified organism (GMO) algae strain, the Algae Raceway Integrated Design (ARID) cultivation system, the electrocoagulation harvesting system, and Hydrothermal Liquefaction-Catalytic Hydrothermal Gasification (HTL-CHG) extraction systems. Results indicate that with the combination of all the most promising NAABB technologies the total cost per gallon of HTL-CHG oil is $\$ 7.40$ with no reductions in CAPEX and OPEX, but can be reduced to $\$ 2.80 /$ gallon if CAPEX and OPEX are reduced by 50\%. CAPEX and OPEX to convert algal oil to a final fuel are not included in the analysis.
\end{abstract}

Key Words: Electrocoagulation; Hydrothermal Liquefaction-Catalytic Hydrothermal Gasification; Algae Raceway Integrated Design (ARID); Monte Carlo Simulation; Farm-level Algae Model (FARM); Cost of Production 


\subsection{Introduction}

In 2010, the United States Department of Energy's office of Biomass Programs funded the National Alliance for Biofuels and Bioproducts (NAABB), which is a public-private partnership of 39 universities, companies, and U.S. national laboratories. NAABB was tasked with developing innovative technologies that would make algae-based biofuels a sustainable, commercially viable industry. Accordingly, technologies were developed along the entire algal biofuels value chain - biology, cultivation, harvesting, extraction, conversion, bioproducts, and economic/energy-balance modeling and resource management.

Similar to NAABB, the United States government funded the Aquatic Species Program (ASP) in the 1990's to evaluate the feasibility of algal production. From this, came one of the seminal papers on algae economics. This paper, by Benemann and Oswald, detailed the most promising technologies from ASP [1]. At the time, it was a hypothetical scenario because it was uncertain if all the technologies would work together. In the report, they used the incremental costs of production from each of the steps to arrive at a final cost of production. They estimate costs between $\$ 39$ and $\$ 69$ per barrel of algal oil (1994 dollars; $\$ 62.19$ and $\$ 110.02$, respectively, 2014 dollars). While this article remains one of the most cited, it does not include any risk analysis.

In 1988, Tapie and Bernard conducted a literature review for algae production in large scale production facilities [2]. They found total production costs ranging from $\$ 0.15$ to $\$ 4.00$ per kilogram $(\$ 0.30$ to $\$ 7.99,2014$ dollars) of unprocessed biomass. A couple decades later interest was renewed in evaluating the economics of algae production. Huntley and Redalje estimate algal oil production costs at $\$ 84 / \mathrm{bbl}, 2004$ dollars $(\$ 105.08,2014$ dollars), for a privately funded $\$ 20$ million program [3]. No further details on costs are presented due to the private nature. In 
evaluating the technical feasibility of microalgae for biodiesel production Chisti estimates costs of \$2.95/gallon for open pond and \$3.80/gallon for photobioreactor (PBR), 2006 dollars ( $\$ 3.46$ and \$4.46, 2014 dollars, respectively) [4]. Norsker et al. calculated production costs under Dutch climatic conditions [5]. They estimated biomass production costs (including dewatering) of 4.95, 4.16, and 5.96€/kilogram for open pond, horizontal PBRs, and flat panel PBRs, respectively, 2010 Euros $(\$ 7.12, \$ 5.98, \$ 8.57,2014$ dollars, respectively). In 2010, Lundquist et al. [6] evaluated five different production scenarios for microalgae biofuel and found costs of $\$ 28 / \mathrm{bbl}, \$ 0.17 / \mathrm{kWh}, \$ 332 / \mathrm{bbl}, \$ 0.72 / \mathrm{kWh}$, and $\$ 240 / \mathrm{bbl}(\$ 30, \$ 0.18, \$ 360, \$ 0.76$, and $\$ 247$, 2014 dollars, respectively).

One of the most comprehensive studies available is by Davis et al. [7]. They analyzed open pond and PBR algae farms, each producing 10 million gallons (MG) of lipid per year. Davis et al. found minimum selling prices of $\$ 8.52 /$ gallon of lipid for the open pond farm and \$18.10/gallon of lipid for PBR, 2007 dollars (\$9.71 and \$20.63, 2014 dollars). Based upon the work of Davis et al., Richardson, Johnson, and Outlaw find costs of \$12.74 and \$32.57 per gallon of lipid for open ponds and PBRs, respectively using a Monte Carlo simulation approach (\$14.52 and \$37.12, 2014 dollars) [8]. In 2012, the work by Davis et al. on open ponds was extended in the harmonization report [9]. They found the most profitable scenario to be in operation year round, with a product selling price of $\$ 17.49$ per gallon of algal oil $(\$ 18,2014$ dollars). In 2013, Richardson et al. compared the economic feasibility of open pond and PBR production systems [10]. An emphasis was placed on the differences in biomass production, lipid content, culture crashes, and harvesting and extraction costs. Taking these differences into account, a cost of $\$ 109$ and $\$ 77$ per gal of bio-oil was estimated for the open pond and PBR systems, respectively, (\$112.18 and \$79.25, 2014 dollars). 
Cost estimates have varied widely for algal production based on the systems modeled. Each analysis evaluates new and different combinations of technologies as the industry continues to evolve and move forward. Many of these studies also evaluate technologies, or combinations of, that at the time were hypothetical or had only been tested at the lab scale. This was done to evaluate ex ante the economic feasibility of the technologies and their combinations in an effort to decide whether they should be further pursued. Similar to these previous articles, this research evaluates the economic feasibility of technologies and their combinations that have not been widely tested or tested at scale. Additionally, a mass balance of the potential technologies and their combinations would be valuable, but is not included and was beyond the scope that NAABB undertook. This research is only an initial evaluation of the economic feasibility of technologies and their combinations. It is reasonable to expect that these scenarios could be demonstrated in the future using end-to-end processes that can achieve both energy and mass balances in final demonstration.

Over the past three years, many technologies have been developed and tested by NAABB scientists. Journal articles have also been published detailing the technologies [11, 12]. Many graduate student projects revolved around testing the NAABB technologies. Kovalcik and Morrison each conducted master's research regarding the electrocoagulation harvesting system and found it to be a promising system $[13,14]$. Attalah's master's research evaluated energy use in the Algae Raceway Integrate Design (ARID) cultivation system [15]. Attalah found the ARID high velocity system to be much more energetically efficient than the original ARID design. Additionally, Richardson, Johnson, Lacey, Oyler, and Capareda conducted an economic feasibility analysis comparing two harvesting (centrifuge and electrocoagulation) and three extraction systems (wet solvent, hydrothermal liquefaction-catalytic hydrothermal gasification 
(HTL-CHG), and pyrolysis) [16]. They find the electrocoagulation and HTL-CHG systems to be the most economically efficient.

As NAABB progressed it began to down-select to the most promising technologies that could provide a pathway to sustainable, commercially viable algal-based biofuels. The NAABB closeout report was written in 2014 detailing all of the processes that had been evaluated [17]. It also recommended the selected technologies showing the most promise. These technologies include a GMO algae strain, the ARID cultivation system, electrocoagulation harvesting system, and the HTL-CHG extraction system. This paper serves to share the final economic analysis of the selected technologies in the NAABB program.

\subsection{Data \& Methods}

Data from NAABB's Algal Biology, Cultivation, Harvesting and Extraction, Conversion, Ag-coproducts and Sustainability teams were used for an economic/financial feasibility of selected NAABB technologies. Data from the different NAABB teams were used to update the techno-economic data reported initially by NREL [7]. Processes and parameters not detailed in this paper remained the same from the NREL report. Process modeling was completed by other NAABB participants, but is not included in this analysis. The techno-economic information from NREL was then combined with biomass production distributions developed by PNNL and a NAABB specific economic model (FARM) of algal crude oil production [18]. For this analysis, the information for alternative cultivation, harvesting and extraction systems was provided by the investigators responsible for developing the technologies. The PIs provided information on the operating and capital expenses and throughput capacity of their respective technologies at a commercial-size scale. This information is provided in the Appendix ${ }^{1}$.

\footnotetext{
${ }^{1}$ The CAPEX values were developed in consultation with the originators of the technologies. The four technologies have not been coupled into a fully integrated scaled up process and the GMO technology has yet to be demonstrated
} 
The Farm-level Algae Risk Model (FARM) is a Monte Carlo firm level economic/financial simulation model developed by NAABB for analyzing the financial feasibility of algae farms. The model is designed to facilitate analysis of the probability of economic returns and costs of crude oil production for an algae farm under alternative management/technology systems. The model is an integrated systems compilation of several techno-economic models for different phases of a commercial algae farm, but it does not stop there as it includes the financial, marketing, and income tax aspects of a business. The simulation results provide estimates of the probability of economic success for different pathways, as well as the costs of production for algae crude oil and the sensitivity of the costs of production to changes in capital expenses (CAPEX) and operating expenses (OPEX).

\subsection{NAABB Technologies}

The economic feasibility of alternative NAABB technologies for the production of algae biofuels was analyzed. The technologies discussed in this paper were all demonstrated at sufficient scale to provide adequate information, showed promise for reducing costs over baseline, decreased overall energy utilization, and showed potential for scalability (Table 1). In addition, an evaluation was included for GMO data from a laboratory scale strain of algae showing the potential for substantial productivity improvements. The four technologies selected for this financial analysis show significant gains in lowering costs, reducing energy input requirements, increasing production, and receipts. For example, HTL-CHG reduces energy consumption by $98 \%$ by not having to dry LEA, the GMO strain increases production $250 \%$, and ARID increases receipts $27 \%$ (Tables 6-7).

at scale or in the outdoors. Therefore, both the CAPEX and OPEX values utilized in this study are limited and do not represent a system with full mass and energy balance understanding. Such scale up and integration can be undertaken if these preliminary analyses demonstrate economic feasibility for the appropriate combination of technologies. 
Centrifuges were used as the base harvesting technology in NAABB. They are a proven technology and have been used in algal harvesting for many years [1]. Throughout the years, however, centrifuge economics for harvesting algae have been found to be very difficult due to the large amounts of water that must be processed. Data for simulating the centrifuge comes from Perry's Chemical Engineer's Handbook [19].

A wet solvent extraction system developed by Solvent Recovery Systems (SRS) (now Valicor Renewables, LLC) was used by NAABB as the base extraction system for comparison. In the wet solvent extraction process the harvested algae biomass is pretreated at a precise $\mathrm{pH}$, temperature and residence times. This is then followed by a non-polar solvent addition and proprietary lipid extraction techniques. In the conditioning step the algae cells are hydrated and chemically solubilized to enable the non-polar solvent to remove lipids. Phase separation of the algal mass then occurs and the lipids are extracted from the non-polar solvent by distillation. Solvent, water and conditioning chemicals are recycled while value added products (algal crude oil and lipid extracted algae) are derived from processed biomass. Because lipid extracted algae (LEA) is produced for sale, there are no nutrients available for recycling to cultivation.

Information was provided by the Vice-President of Valicor, Brian Goodall, for the wet solvent extraction process [20].

The alternative harvesting method within NAABB was the electrocoagulation (EC) harvesting system. The EC utilizes metal ions to create algal flocs. A number of metals can be used, including aluminum and stainless steel. The metal ions are released during electrolysis between two metal plates submerged in the media. Positively charged metal ions attract the negatively charged algae and create a floc. The floc then settles to the bottom of the media and is separated by decanting the clear media from the top, which can be recycled to the cultivation 
process. The algae are concentrated from approximately $1 \mathrm{~g} / \mathrm{L}$ in cultivation to around $8 \%$ solids $(80 \mathrm{~g} / \mathrm{L})$ in the sediment. The capacity of the electrocoagulation unit is determined by the size of the plates, the electrode material, and the volume of the reactor chamber. Stainless steel electrodes were evaluated to avoid ion release that reduces the value of LEA for animal feed. Kovalcik compared centrifugation and electrocoagulation as harvesting methods in algal production for bio-fuels [13]. He found that electrocoagulation is an effective harvesting method that is at a high technological readiness level and has significant cost savings compared to centrifugation. Morrison evaluated the cost and effectiveness of the electrocoagulation system, finding that the algae concentration after treatment and settling is $8 \%$ [14]. Information for the EC harvesting process comes from the NAABB final report to the DOE, harvesting chapter [17]. Additional information about the electrocoagulation system can be found in articles by Uduman, et al., Aragon, et al., Alfafara et al., Poelman, et al., and Emamjomeh and Sivakumar [21-25].

Hydrothermal Liquefaction-Catalytic Hydrothermal Gasification is an extraction process in which algae biomass is transformed into oil, and methane for electricity. Other output streams from this process include phosphate, $\mathrm{CO}_{2}$, sterile water, and other nutrients that can be recycled. The harvested algae are made into slurry. The algae slurry is heated and pressurized. The output from this step is a crude consisting of oil and effluent water, along with a solid precipitate. The phosphate precipitates can be recovered and sent for remake, after which it can be recycled to the ponds. Once the oil and water are separated the oil can be upgraded similar to a petroleum crude oil. The effluent water is sent on to CHG for further processing. Once the effluent water reaches the $\mathrm{CHG}$ process it is again made into a slurry that is heated and pressurized to produce a liquid and precipitate that can be processed and recycled. The liquid is then combined with a catalyst in the gasifier to produce $\mathrm{CH}_{4}$ and $\mathrm{CO}_{2}$. This $\mathrm{CH}_{4}$ can be sold or turned into electricity, heat or 
compressed natural gas $(\mathrm{CNG})$ and the $\mathrm{CO}_{2}$ can be recycled to the ponds. Any remaining gas/water mixture can be further separated to obtain the $\mathrm{CO}_{2}$ from the water and nutrients mixture. Then, each of these products can then be recycled to the ponds. Information for HTLCHG extraction comes from the NAABB final report to the DOE, extraction chapter [17]. Additionally, more technical details on the HTL-CHG processing systems can be found in Elliott et al., Sealock et al., and Elliott et al. [12, 26, 27]. Capital and operating expenses used are for a HTL-CHG system that accommodates an $8 \%$ solid input.

In the GMO scenarios (5 and 7) biomass production is increased by $50 \%$ in the winter (October-February), $100 \%$ in the spring and fall (March, July-September), and 200\% in the summer (April-June); lipid content is increased to 50\% and the probability of pond crashes is reduced 50\%. It is assumed that these improvements can be made with no changes in CAPEX or OPEX. This information and values are based on information from the NAABB final report to the DOE, biology chapter [17] as well as Perrine, Negi, and Sayre [11].

The ARID cultivation system was designed to improve temperature control which increases algae production. The ARID system includes a deep canal and a serpentine flow path through shallow channels. Temperature is regulated by varying the water surface area between day and night. Removing the water from the serpentine channels at night reduces long wave radiation to the night sky and convective heat loss. The ARID system reduces energy input through recirculation of water in the channel area and only drops water into the canal when necessary for temperature management, cleaning, or harvesting. Another advantage of the ARID system is the lower capital cost since it uses no paddlewheels and other cost-minimization strategies. Information for ARID was obtained from the NAABB final report to the DOE, cultivation chapter [17]. 


\subsection{FARM Model}

Microsoft@ Excel along with Simetar@ were used to program FARM. FARM depends upon the Simetar@ add-in to incorporate risk. Simetar is used to estimate parameters for probability distributions of random variables and to simulate Monte Carlo models. Extensive use has been made of Simetar for risk analysis in business models and prospective businesses [28]. The FARM model is divided up into multiple worksheets including, Input, Model, SimData, Prices, and stochastic routines.

The INPUT worksheet is used to enter all input for algae farms and most calculations are made in the MODEL worksheet. Annual stochastic prices, production, and costs from known probability distributions are randomly drawn by Simetar for use in simulating the model. Historical data, provided as input by the researchers, are used to estimate the parameters for price probability distributions. The monthly biomass production for alternative farm locations are simulated by the Pacific Northwest National Laboratory (PNNL)'s Biomass Assessment Tool (BAT) model [29]. BAT produced monthly biomass yields for 30 years based on simulated monthly weather data for the farm sites. The 30 years of monthly data from the BAT model were used in the FARM to estimate a multivariate probability distribution of monthly biomass, lipid content, and water consumption. The multivariate distributions are used to simulate production of biomass, lipid, lipid extracted algae (LEA), hydrothermal liquefaction (HTL) biooil, and methane, and their associated cost of production and revenues. The BAT monthly biomass probability distributions were scaled up on a relative basis to accommodate the scenario of increased biomass production due to the introduction of GMO algae.

The FARM model is simulated recursively for 10 years, which means that the ending cash position in year 1 of the business is the beginning cash flow position in year 2, and so on. 
Five hundred different draws of stochastic prices and production values are used for the 500 iterations simulated for each year of the 10 year planning horizon. The model is able to simulate most combinations of the stochastic variables, (i.e., the best and worst cases and those in between) by simulating the 10 year planning horizon for 500 iterations, based on their respective probabilities of being observed. The empirical probability distributions estimated for the key output variables (KOVs) are the resulting 500 values for each variable and are then used to calculate probabilities of financial and economic sustainability $[8,10,16,30]$.

To simulate a farm, analysts must enter all of the data to describe the scenario. Input data include information for: the cultivation type, average ending cell density, lipid content, algal productivity, harvesting, lipid extraction, and co-products use. Usually a base scenario is defined and copied multiple times with marginal variations in the plethora of technology or management control variables to create the alternative scenarios. The FARM model simulates the same number of random variables for all scenarios and uses options to select the input information for the technologies in use, thus ensuring that by using a pseudo random number generator in the model that each scenario uses the same risk for the stochastic variables. Only in this way can one be absolutely sure that the scenarios can be compared directly since the only difference between scenarios is the input data.

Stochastic monthly production of algae biomass is simulated by the model and is then subsequently used to simulate the lipid production. The model calculates the number of harvesting and dewatering units based on the stochastic culture volume at harvest and the unit throughput of the harvesting and dewatering systems. Using this information, the capital cost of the harvesting system is calculated. Harvesting system operational costs include electricity, chemicals, labor and maintenance. Extraction costs are a based on the system used, the quantity 
of biomass, the strain of algae used and its concentration (percent solids), electricity, labor costs, and solvent requirements. Stochastic annual rates of inflation are used to inflate the initial costs for annual maintenance, overhead, management, and fixed costs. The discount rate is $10 \%$ and the interest rate is $8 \%$ of the costs financed $(60 \%)$. Depreciation is calculated using the straightline method, based on IRS code for the reasonable life of each piece of machinery, and is used to reduce taxable income.

Key output variables (KOV)'s, net cash income, ending cash reserves, and net worth for each year of the 10 year planning horizon, are calculated using economic variables such as: receipts, expenses, interest, taxes, dividends, and principal payments. Net present value is used to summarize the overall net returns to the farm, reflecting the overall returns to the business in today's dollars. The business is considered an economic success if the net present value is positive, in other words, if the farm's internal rate of return exceeds the discount rate.

Probability distributions for annual net cash farm income, cost of production for a gallon of crude bio-oil, ending cash reserves, and net present value are estimated by FARM. The estimated probability distributions show the range or risk associated with the KOVs as well as the mean. For example, an estimate of the $95 \%$ confidence interval about the estimated mean cost of production for a gallon of crude algal oil is provided by the model. Furthermore, the skewness associated with the KOVs is shown by the probability distributions; therefore, stakeholders have a risk estimate associated with alternative algae oil pathways.

A reduced number of KOVs from FARM are used to summarize the results from analyzing the alternative technology scenarios reported in this paper. Net present value and probability of economic success are used to report the overall profitability of an algae farm scenario. Average net present value is the average net increase in wealth plus annual income 
earned by investing in an algae farm, expressed in 2013 dollars. A negative net present value indicates the investment failed to return a rate of return in excess of the investor's assumed discount rate of $10 \%$. The probability of economic success is the probability that the farm scenario generates a positive net present value, i.e., that the internal rate of return exceeds the $10 \%$ discount rate. Each scenario was simulated for 100 combinations reducing CAPEX and OPEX in $10 \%$ increments from 0 to $90 \%$. This results in a matrix of 100 average net present values and probabilities of economic success. The resulting matrix provides a sensitivity analysis indicating the potential profitability if CAPEX and OPEX can be reduced by alternative fractions. The projected average total costs per gallon of algae crude oil and ton of biomass are reported for each of the 100 combinations of CAPEX and OPEX. Total cost equals the estimated total cash cost of production plus depreciation costs minus credits for byproducts such as LEA and methane. Each of the KOV's is presented using the 10x10 matrix for alternative reductions in CAPEX and OPEX. The values in the tables are color-coded using a stoplight scheme of red, yellow, and green for bad, marginal, and good, respectively.

\subsection{Scenarios}

In total, seven scenarios based on combining the four NAABB technology innovations in Table 1 are evaluated. Each technology represents a different NAABB work group and contributes to significant decreases in total costs of producing algal crude oil relative to the base NAABB technology (Figure 1). In addition to analyzing the economic and financial feasibilities of these technologies, paths forward to further reduce costs and increase the probability of success will be described.

The seven scenarios analyzed focused exclusively on fuel. These scenarios show the synergistic effect of new technology innovations as they are brought to bear on the process of 
producing algae crude oil. The different combinations of technology improvements from biology, cultivation, harvesting, and extraction are summarized in Table 2. In each scenario, we modified the CAPEX and OPEX reported by Davis, et al. (2013) based on improvements and data from NAABB innovations [9]. Scenario 1 is the NAABB baseline with current algae productivity levels and uses conventional methods for cultivation (lined open ponds) of a Chlorella sp., harvesting (centrifugation), and wet-solvent extraction. Scenario 2 highlights the economic contributions of using EC in place of centrifuges for harvesting. Scenario 3 highlights the improvements in economic contributions of the ARID cultivation system and its associated increased productivity. The comparison of scenario 1 to scenario 4 allows one to quantify the economic gains of HTL-CHG over using wet solvent extraction and conventional algae production and harvesting parameters. Scenario 5 combines the improvements in harvesting (EC), extraction (HTL-CHG), and increased algae productivity due to utilization of a GMO strain. The total economic gains in scenario 5 can be compared to scenario 1 to evaluate the improvement since the beginning of NAABB. Scenario 6 is used to highlight the economic contributions of the ARID cultivation system with the EC and HTL-CHG systems and their associated increased productivity. Scenario 7 includes all synergistic improvements from the above NAABB innovative technologies (GMO, ARID, EC, and HTL-CHG).

Each scenario in Table 2 was programmed in FARM. Algae farms for scenarios 1, 2, 4, and 5 are assumed to be located in Pecos, Texas, while scenarios 3, 6, and 7 are located in Tucson, Arizona. The ARID scenario algae farms are located in Tucson, Arizona, because that is the only location where the ARID raceway system has been tested. 
A summary of the assumptions for the seven scenarios is provided in Tables 3 and 4. Biomass production, harvesting and extraction throughput capacity, and CAPEX differences are highlighted in the tables and reflect information provided by the technology developers.

\subsection{Results}

The total economic plus financial costs per gallon of algae crude oil for the seven scenarios and the individual NAABB innovations are summarized in Figure 2. The costs reflect the total costs simulated from the FARM model assuming no reductions in CAPEX and OPEX beyond what the technologies themselves have contributed. The pre-NAABB economic plus financial cost of production for a gallon of crude oil is calculated to be more than $\$ 240 /$ gallon. Each NAABB technology analyzed in scenarios 2-7 contributes to reducing total costs. The combination of the ARID, EC, HTL-CHG, and GMO technologies in scenario 7 developed and tested by NAABB reduce the total cost from $\$ 240 /$ gallon to $\$ 7.40 /$ gallon.

Table 5 summarizes the results for all seven technology scenarios. The reduction in CAPEX and OPEX rows show the respective fractional reductions needed for the algae farm to obtain a reasonable probability of economic success (Row 3 of Table 5). There are two probabilities of success listed for each scenario, e.g., $0.0-55 \%$ in scenario 7 . The first probability is the probability of economic success for the farm when neither CAPEX nor OPEX is reduced. The second value is the probability of economic success when the reductions in CAPEX and OPEX in rows one and two are used. In scenario 7, for example, when the algae farm does not reduce its CAPEX or OPEX the farm has a zero probability of success. However, when the farm reduces its OPEX by $50 \%$ and CAPEX by $50 \%$, the farm has a $55 \%$ probability of economic success. The average total costs (\$/gal of crude oil) in Table 5 are for the assumed reductions in CAPEX and OPEX. Assuming a 50\% reduction in both CAPEX and OPEX the total cost (\$/gal 
of crude oil) for scenario 7 averages $\$ 2.84 /$ gallon with a $95 \%$ confidence interval of $\$ 2.53 /$ gallon and \$3.48/gallon. The confidence intervals are similar to reporting error bars, but confidence intervals are more robust because they report the $95 \%$ confidence interval about the mean rather than a one standard deviation from the mean.

In the scenarios 2-6 substantial reductions in CAPEX and OPEX are required to provide a reasonable probability of economic success, as shown in Table 5. For example, scenario 4 would require an $80 \%$ reduction in CAPEX and a 90\% reduction in OPEX to achieve an $89 \%$

probability of success. Scenario 7 requires the most reasonable reduction in CAPEX and OPEX of $50 \%$ to achieve a $55 \%$ chance of economic success. The results for scenario 7 are highlighted as it represents the synergies of the four NAABB innovations and has a moderate probability of economic success at more reasonable cost reduction levels.

The average net present value for each fractional reduction in CAPEX and OPEX for scenario 7 is summarized in Table 6. Average net present value reports the average net increase in wealth and income earned by investing in an algae farm, expressed in 2013 dollars. When net present value is negative the investment failed to return a rate of return in excess of the investor's discount rate of $10 \%$. There are 41 combinations of CAPEX and OPEX reduction in scenario 7 that return positive average net present values. Positive net present values are likely if CAPEX and OPEX are reduced $50 \%$ or more and if either CAPEX or OPEX is reduced further the algae farm will be even more profitable.

The probability of economic success for each combination of fractional reductions in CAPEX and OPEX for the algae farm in scenario 7 is reported in Table 6. There are 36 combinations of reductions in CAPEX and OPEX that result in probabilities of economic success greater than $75 \%$. Total costs of production for algae crude oil and algae biomass are presented 
in Table 7. The total cost per gallon is $\$ 7.40$ with no reductions in CAPEX and OPEX, but can be reduced to $\$ 2.80 /$ gallon if CAPEX and OPEX are reduced by $50 \%$ each. That is, if total CAPEX and OPEX costs are each reduced by $50 \%$ then this will result in a total cost per gallon of $\$ 2.80 /$ gallon. If CAPEX and OPEX can both be reduced by $70 \%$ the cost of algae crude oil falls to $\$ 1.50 /$ gallon. The cost of biomass is calculated at $\$ 1,033 /$ ton if CAPEX and OPEX are not reduced and \$395/ton if both CAPEX and OPEX can be reduced 50\% (Table 7). A range of CAPEX and OPEX reduction fractions are presented as a sensitivity analysis because it is unknown what technologies and processes can be improved or have their costs cut to achieve the reduction fractions. The reduction values only serve as an overall benchmark for obtaining economic success.

\subsection{Summary}

The results from simulating a large algae farm with technologies developed by NAABB scientists suggest that algal crude oil could be financially feasible if CAPEX and OPEX can be further reduced. However, the NAABB innovations remain untested in large outdoor raceways. Scenario 1, with the base technology had a zero probability of economic success, even when CAPEX and OPEX were reduced by $90 \%$. Scenario 7 analyzed the reduction in both CAPEX and OPEX. Results indicate that with the combination of the most promising NAABB technologies (GMO, ARID, EC, and HTL-CHG) the total cost per gallon is $\$ 7.40$ with no reductions in CAPEX and OPEX, but cost can be reduced to $\$ 2.80 /$ gallon if CAPEX and OPEX are reduced by $50 \%$. The commercial production of algae for biofuels is not economically or financially feasible at this time, but, as the results show, the combination of improvements in strain characteristics, cultivation, harvesting, and extraction can increase the likelihood of economic viability. After identifying economically viable combinations, a mass balance would 
be useful for determining the feasibility of the technologies and their combinations in a proposed area. Great strides have been made by the NAABB consortium, but continued enhancements are needed in algal biology, and would be further useful in the areas of cultivation, harvesting, and extraction. The improvements required cannot all be achieved by any one area of production. It will require improvements in each step of the production process.

Based on the risk analysis the greatest risk associated with algae farming comes from algae production. Risk due to weather, seasonal variability, pond crashes, and predators all contribute to the production risk of algae. Additionally, risk for the percent of lipids is a significant factor in the risk or profits. Risk for prices of inputs and the price of algal crude cannot be ignored, but their combined influence is secondary to the risk on production of algae or lipid.

Acknowledgements: Funding for this project was provided in part by the US Department of Energy through contract DE-EE0003046 to the National Alliance for Advanced Biofuels and Bioproducts (NAABB) and Texas A\&M Agrilife Research. 


\section{References}

[1] Benemann, J.R. and W.J. Oswald. 1996. "Systems and Economic Analysis of Microalgae Ponds for Conversion of $\mathrm{CO} 2$ to Biomass." Final Report to the Department of Energy. Pittsburgh Energy Technology Center.

[2] Tapie, P. and A. Bernard. 1988. "Microalgae Production: Technical and Economic Evaluations." Biotechnology and Bioengineering. 32:873-885.

[3] Huntley, M.E., and D.G. Redalje. 2007. "CO2 Mitigation and Renewable Oil from Photosynthetic Microbes: A New Appraisal." Mitigation and Adoption Strategies for Global Change. 12:273-608.

[4] Chisti, Y. 2007. "Biodiesel from Microalgae.” Biotechnology Advances. 25:294-306.

[5] Norsker, N., M.J. Barbosa, M.H. Vermue, and R.H. Wijffels. 2010. "Microalgal Production A Close Look at the Economics." Biotechnology Advances. 29:24-27.

[6] Lundquist, T., I. Woertz, N. Quinn, and J. Benemann. "A Realistic Technology and Engineering Assessment of Algae Biofuel Production.” Energy Biosciences Institute Report October 2010.

[7] Davis, R., A. Aden, P.T. Pienkos. 2011. "Techno-Economic Analysis of Autotrophic Microalgae for Fuel Production.” Applied Energy. 88:3524-3531.

doi:10.1016/j.apenergy.2011.04.018.

[8] Richardson, J.W., M.D. Johnson, J.L. Outlaw. 2012. "Economic Comparison of Open Pond Raceways to Photo Bio-reactors for Profitable Production of Algae for Transportation Fuels in the Southwest." Algal Research. 1:93-100.

[9] ANL; NREL; PNNL (2012). "Renewable Diesel from Algal Lipids: An Integrated Baseline for Cost, Emissions, and Resource Potential from a Harmonized Model," June 2012. ANL/ESD/12-4; NREL/TP-5100-55431; PNNL-21437. http://www.nrel.gov/docs/fy12osti/55431.pdf

[10] Richardson, J.W., M.D. Johnson, X. Zhang, P. Zemke, W. Chen, and Q. Hu. 2014. “A Financial Assessment of Two Alternative Cultivation Systems and Their Contributions to Algae Biofuel Economic Viability.” Algal Research. 4:96-104. http://dx.doi.org/10.1016/j.algal.2013.12.003

[11] Perrine, Z., S. Negi, and R.T. Sayre. 2012. "Optimization of Photosynthetic Light Energy Utilization by Microalgae.” Algal Research. 1:134-142. Doi:10.1016/j.algal.2012.07.002.

[12] Elliott, D.C., et al. 2013. "Process Development for Hydrothermal Liquefaction of Algae Feedstocks in a Continuous-flow Reactor." Algal Research. 2:445-454. http://dx.doi.org/10.1016/j.algal.2013.08.005. 
[13] Kovalcik, D. “Algal Harvesting for Biodiesel Production: Comparing Centrifugation and Electrocoagulation." Department of Biological and Agricultural Engineering, Texas A\&M University, Master of Science Thesis, August 2013.

[14] Morrison, T. "Electrolytic Methods As A Cost And Energy Effective Alternative Of Harvesting Algae For Biofuel.” Department of Biological and Agricultural Engineering, Texas A\&M University, Master of Science Thesis, December 2012.

[15] Attalah, S., P. Waller, G. Khawam, and R. Ryan. "Energy Evaluation in the High Velocity Algae Raceway Integrated Design (ARID-HV)." American Society of Agricultural and Biological Engineers (ASABE) 2012 Meeting Presentation. Dallas, Texas.

[16] Richardson, J.W., M.D. Johnson, R. Lacey, J. Oyler, and S. Capareda. 2014. "Harvesting and Extraction Technology Contributions to Algae Biofuels Economic Viability." Algal Research. 5:70-78.

[17] United States Department of Energy. Office of Energy Efficiency and Renewable Energy. "National Alliance for Advanced Biofuels and Bioproducts (NAABB) Final Report." July 2014. http://www.energy.gov/eere/bioenergy/downloads/national-alliance-advancedbiofuels-and-bioproducts-synopsis-naabb-final.

[18] Richardson, J.W. and M.D. Johnson. “Algae Income Simulation Model: AISIM.” Texas A\&M University, Agricultural and Food Policy Center Research Report 12-4. December 2012.

[19] Perry, R. H., D. W. Green, and J. O. Maloney. Perry's Chemical Engineer's Handbook, Seventh Edition. McGraw-Hill, New York. 1997.

[20] Goodall, Brian. Valicor. http://www.valicor.com/renewablestechnology.aspx. Accessed 4$25-14$.

[21] Uduman, N., et al. 2010. "Dewatering of Microalgal Cultures: A Major Bottleneck to Algae-based Fuels.” Journal of Renewable and Sustainable Energy. 2:012701-1 012701-15.

[22] Aragon, A. B., R. B. Padilla and J. A. Fiestas Ros de Ursinos. 1992. "Experimental Study of the Recovery of Algae Cultured in Effluents from the Anaerobic Biological Treatment of Urban Wastewaters.” Resources, Conservation and Recycling. 6:293-302.

[23] Alfafara, G. H., K. Nakano, N. Nomura, T. Igarashi, and M. Matsumura. 2002. "Operating and Scale-up Factors for the Electrolytic Removal of Algae from Eutrophied Lakewater." Journal of Chemical Technology and Biotechnology. 77:871-876.

[24] Poelman, E, N. De Pauw, and B. Jeurissen. 1997. "Potential of Electrolytic Flocculation for Recovery of Micro-algae." Resources, Conservation and Recycling. 19:1-10. 
[25] Emamjomeh, M.M. and M. Sivakumar. 2009. "Review of Pollutants Removed by Electrocoagulation and Electrocoagulation/Flotation Processes." Journal of Environmental Management. 90:1663-1679.

[26] Sealock, J.L., et al., 1996. "Chemical Processing in High-Pressure Aqueous Environments. 5. New Processing Concepts." Industrial and Engineering Chemistry Research. 35:41114118.

[27] Elliott, D.C., et al., PNNL. (October 2009). “Catalytic Hydrothermal Gasification of LigninRich Biorefinery Residues and Algae.” PNNL-DE-AC06-76RL01830. Richland, WA:

Pacific Northwest National Laboratory.

[28] Richardson, J.W., K. Schumann, and P. Feldman. 2005. "Simetar: Simulation for Excel to Analyze Risk.” Department of Agricultural Economics, Texas A\&M University, College Station, Texas.

[29] Wigmosta, M.S., A.M. Coleman, R.J. Skaggs, M.H. Huesemann, and L.J. Lane, 2011. "National Microalgae Biofuel Production Potential and Resource Demand." Water Resources Research.47(3).

[30] Richardson, J.W. and M.D. Johnson. 2014. "Economic Viability of a Reverse Engineered Algae Farm (REAF)." Algal Research 3:66-70. 
Table 1. Comparison of baseline and NAABB technologies considered for financial feasibility analysis.

\begin{tabular}{|c|c|c|c|}
\hline Baseline Technology & $\begin{array}{l}\text { NAABB Technology as } \\
\text { Demonstrated }\end{array}$ & Benefit of Innovation & $\begin{array}{l}\text { Scalability of NAABB } \\
\text { Technology }\end{array}$ \\
\hline $\begin{array}{l}\text { Centrifugation } \\
-\quad \text { Ubiquitous use in } \\
\text { test beds }\end{array}$ & $\begin{array}{ll}\text { EC } \\
- & \text { Pilot scale validation } \\
- & 3,000 \mathrm{~L} / \mathrm{hr} \\
- & \text { Tested with } \\
& \text { Chlorella } \mathrm{sp} .\end{array}$ & $\begin{array}{ll}\text { - } & \text { Produces a low } \\
\text { mineral product } \\
\text { contamination } \\
\text { (flocculation mode) } \\
- & 17 \% \text { lower CAPEX } \\
\text { than centrifuge } \\
- & 3 \% \text { lower OPEX } \\
- & 9 \% \text { higher recovery } \\
& \text { efficiency }\end{array}$ & $\begin{array}{l}\text { Available } \\
\text { commercially @ } \\
\text { 270,000 L/hr } \\
\text { processed in } \\
\text { commercial unit }\end{array}$ \\
\hline $\begin{array}{l}\text { Open lined ponds } \\
\text { - } \\
\text { Pecos traditional } \\
\text { paddle wheel } \\
\text { raceway at } 23,000 \mathrm{~L} \\
\text { - }\end{array}$ & $\begin{array}{ll}\text { ARID } \\
- & 24,000 \mathrm{~L} \text { open pond } \\
- & \text { Seasonal data used } \\
- & \text { Validated process } \\
& \text { model for production }\end{array}$ & $\begin{array}{ll}\text { - } & 27 \% \text { increase in } \\
\text { receipts } \\
- & 38 \% \text { increase in } \\
\text { annual productivity } \\
\text { - } \\
\text { Increased harvest } \\
\text { concentration to } 1 \\
\text { g/L }\end{array}$ & $\begin{array}{l}\text { - Patent available for } \\
\text { licensing }\end{array}$ \\
\hline $\begin{array}{ll} & \text { Wet-solvent extraction } \\
- & \text { Valicor based } \\
\text { technology } \\
-\quad \\
\text { - } & 96 \% \text {-20\% solids used } \\
& \text { efficiency of crude } \\
& \text { lipid }\end{array}$ & $\begin{array}{l}\text { HTL-CHG } \\
-\quad \text { All work done in } \\
\text { continuous reaction } \\
\text { systems }(2 \mathrm{~L} / \mathrm{hr}) \\
-\quad \text { Used } 10-30 \% \text { solids }\end{array}$ & $\begin{array}{ll}- & 75 \% \text { reduction in } \\
& \text { OPEX } \\
- & 60 \% \text { increase in } \\
& \text { receipts } \\
- & \text { Solvent free process } \\
- & 280 \% \text { increase in } \\
& \text { crude yield } \\
- & \text { Methane sold } \\
- & 98 \% \text { reduction in } \\
& \text { energy consumption } \\
- & \text { Up to 85\% of } \\
\text { biomass carbon } \\
\text { captured } \\
- & \text { Potential for } \\
\text { recycling of water } \\
\text { and nutrients }\end{array}$ & $\begin{array}{l}\text { Design and } \\
\text { construction of a } 1 \\
\text { ton/day processing } \\
\text { unit in progress }\end{array}$ \\
\hline $\begin{array}{l}\text { C. sorokiniana }(D O E- \\
\text { 1412) } \\
-\quad \text { NAABB prospect } \\
\quad \text { strain }\end{array}$ & $\begin{array}{ll}\text { GMO } \\
-\quad \text { Extrapolation of } \\
\text { modified laboratory } \\
\text { strain of } C \text {. } \\
\quad \text { reinhardtii cultured } \\
\quad \text { in PBRs }\end{array}$ & $\begin{array}{ll}- & 240 \% \text { increase in } \\
\text { receipts } \\
-\quad 250 \% \text { increase in } \\
\text { biomass productivity }\end{array}$ & $\begin{array}{ll}\text { - } & \text { Moving genetic } \\
\text { traits into Chlorella } \\
\text { production strains } \\
\text { - } \\
\text { Permitting } \\
\text { requirements to be } \\
\text { addressed }\end{array}$ \\
\hline
\end{tabular}


Table 2. Summary of the technologies analyzed for the seven alternative scenarios.

\begin{tabular}{|c|c|c|c|c|c|c|c|}
\hline & Scenario 1 & Scenario 2 & Scenario 3 & Scenario 4 & Scenario 5 & Scenario 6 & Scenario 7 \\
\hline Products & $\begin{array}{l}\text { Crude } \\
\text { TAG }^{1} \& \\
\text { LEA }\end{array}$ & Crude TAG \& LEA & $\begin{array}{l}\text { Crude TAG } \\
\& \text { LEA }\end{array}$ & $\begin{array}{l}\text { Algae Crude } \\
\text { Oil \& } \\
\text { Methane }\end{array}$ & $\begin{array}{l}\text { Algae } \\
\text { Crude Oil \& } \\
\text { Methane }\end{array}$ & $\begin{array}{l}\text { Algae } \\
\text { Crude Oil \& } \\
\text { Methane }\end{array}$ & $\begin{array}{l}\text { Algae } \\
\text { Crude Oil \& } \\
\text { Methane }\end{array}$ \\
\hline Cultivation & $\begin{array}{l}\text { Open Pond } \\
\text { w/ Liners }\end{array}$ & $\begin{array}{l}\text { Open Pond w/ } \\
\text { Liners }\end{array}$ & $\begin{array}{l}\text { ARID w/ } \\
\text { Liners }\end{array}$ & $\begin{array}{l}\text { Open Pond } \\
\text { w/ Liners }\end{array}$ & $\begin{array}{l}\text { Open Pond } \\
\text { w/ Liners }\end{array}$ & $\begin{array}{l}\text { ARID w/ } \\
\text { Liners }\end{array}$ & $\begin{array}{l}\text { ARID w/ } \\
\text { Liners }\end{array}$ \\
\hline $\begin{array}{l}\text { Biology } \\
\mathrm{g} / \mathrm{m}^{2} / \mathrm{d}\end{array}$ & $\begin{array}{l}\text { Generic } \\
7.4\end{array}$ & $\begin{array}{l}\text { Generic } \\
7.4\end{array}$ & $\begin{array}{l}\text { Generic } \\
9.3\end{array}$ & $\begin{array}{l}\text { Generic } \\
7.4\end{array}$ & $\begin{array}{l}\text { GMO } \\
19.4 \\
\end{array}$ & $\begin{array}{l}\text { Generic } \\
9.3\end{array}$ & $\begin{array}{l}\text { GMO } \\
23.2\end{array}$ \\
\hline Harvesting & Centrifuge & $\begin{array}{l}\text { Electrocoagulation } \\
\text { (EC) }\end{array}$ & $\mathrm{EC}$ & Centrifuge & $\mathrm{EC}$ & $\mathrm{EC}$ & $\mathrm{EC}$ \\
\hline Extraction & $\begin{array}{l}\text { Wet } \\
\text { Solvent } \\
\text { Extraction } \\
\end{array}$ & $\begin{array}{l}\text { Wet Solvent } \\
\text { Extraction }\end{array}$ & $\begin{array}{l}\text { Wet Solvent } \\
\text { Extraction }\end{array}$ & HTL-CHG & HTL-CHG & HTL-CHG & HTL-CHG \\
\hline $\begin{array}{l}\text { Nutrient } \\
\text { Recycling }\end{array}$ & No & No & No & Yes & Yes & Yes & Yes \\
\hline $\begin{array}{l}\text { Biomass } \\
\text { Production } \\
\text { (Tons/Yr) }\end{array}$ & 119,900 & 119,900 & 152,200 & 119,900 & 316,800 & 152,200 & 378,600 \\
\hline $\begin{array}{l}\text { Crude Oil } \\
\text { Production } \\
(\text { Gallons/Yr) }\end{array}$ & $4,679,000$ & $5,096,000$ & $6,470,000$ & $13,506,000$ & $42,321,000$ & $20,332,000$ & $50,570,000$ \\
\hline Location & Pecos, TX & Pecos, TX & Tucson, AZ & Pecos, TX & Pecos, TX & Tucson, AZ & Tucson, AZ \\
\hline
\end{tabular}

${ }^{1}$ triacylglycerol (TAG) 
Table 3. Key input parameters for seven scenarios.

\begin{tabular}{|llllllll|}
\hline & Scenario 1 & Scenario 2 & Scenario 3 & Scenario 4 & Scenario 5 & Scenario 6 & Scenario 7 \\
\hline & $\begin{array}{l}\text { Centrifuge }- \\
\text { Wet Solvent }\end{array}$ & $\begin{array}{l}\text { EC - Wet } \\
\text { Solvent }\end{array}$ & $\begin{array}{l}\text { ARID EC-Wet } \\
\text { Solvent }\end{array}$ & $\begin{array}{l}\text { Centrifuge - } \\
\text { HTL-CHG }\end{array}$ & EC- HTL-CHG & $\begin{array}{l}\text { ARID EC- } \\
\text { HTL-CHG }\end{array}$ & $\begin{array}{l}\text { GMO, ARID, } \\
\text { EC, HT-CHG }\end{array}$ \\
\hline Location & Pecos, TX & Pecos, TX & Tucson, AZ & Pecos, TX & Pecos, TX & Tucson, AZ & Tucson, AZ \\
\hline Cultivation & Open Pond & Open Pond & ARID & Open Pond & Open Pond & ARID & ARID \\
\hline $\begin{array}{l}\text { Total Hectares } \\
\text { of Land }\end{array}$ & 4,850 & 4,850 & 4,850 & 4,850 & 4,850 & 4,850 & 4,850 \\
\hline $\begin{array}{l}\text { Total Hectares } \\
\text { of Ponds }\end{array}$ & 4,050 & 4,050 & 4,050 & 4,050 & 4,050 & 4,050 & 4,050 \\
\hline $\begin{array}{l}\text { Total Volume } \\
\text { of Ponds (AF) }\end{array}$ & 9,855 & 9,855 & 2,941 & 9,855 & 9,855 & 2,941 & 2,941 \\
\hline $\begin{array}{l}\text { Total Volume } \\
\text { of Ponds } \\
\text { (millions of } \\
\text { liters) }\end{array}$ & 12,156 & 12,156 & 3.63 & 12,156 & 12,156 & 3.63 & 3.63 \\
\hline $\begin{array}{l}\text { Days of } \\
\text { Operation }\end{array}$ & 330 & & & & & 330 & \\
\hline Harvesting & Centrifuge & EC & EC & Centrifuge & EC & EC & EC \\
\hline
\end{tabular}


Table 4. Operating costs, expenses, capacities, and CAPEX for seven scenarios.

\begin{tabular}{|c|c|c|c|c|c|c|c|}
\hline & Scenario 1 & Scenario 2 & Scenario 3 & Scenario 4 & Scenario 5 & Scenario 6 & Scenario 7 \\
\hline & $\begin{array}{l}\text { Centrifuge - } \\
\text { Wet Solvent }\end{array}$ & $\begin{array}{l}\text { EC - Wet } \\
\text { Solvent }\end{array}$ & $\begin{array}{l}\text { ARID EC-Wet } \\
\text { Solvent }\end{array}$ & $\begin{array}{l}\text { Centrifuge - } \\
\text { HTL-CHG }\end{array}$ & EC - HTL-CHG & $\begin{array}{l}\text { ARID EC- } \\
\text { HTL-CHG }\end{array}$ & $\begin{array}{l}\text { GMO, ARID, } \\
\text { EC, HTL-CHG }\end{array}$ \\
\hline $\begin{array}{l}\text { Harvesting } \\
\text { Throughput } \\
\text { Capacity (L/Hr) }\end{array}$ & 113,560 & 408,780 & 408,780 & 113,560 & 408,780 & 408,780 & 408,780 \\
\hline $\begin{array}{l}\text { Harvesting } \\
\text { Capital Cost } \\
\text { (M\$s/Unit) }\end{array}$ & 0.275 & 0.65 & 0.65 & 0.275 & 0.65 & 0.65 & 0.65 \\
\hline $\begin{array}{l}\text { Number of } \\
\text { Harvesting Units }\end{array}$ & 2,231 & 620 & 185 & 2,231 & 620 & 185 & 185 \\
\hline $\begin{array}{l}\text { Total Harvesting } \\
\text { Capital Cost } \\
(\mathrm{M} \$ \mathrm{~s})\end{array}$ & 613.5 & 403.35 & 120.6 & 613.5 & 403.35 & 120.6 & 120.6 \\
\hline $\begin{array}{l}\text { Harvesting } \\
\% \text { Solids }\end{array}$ & $10 \%$ & $8 \%$ & $8 \%$ & $10 \%$ & $8 \%$ & $8 \%$ & $8 \%$ \\
\hline $\begin{array}{l}\text { Harvesting } \\
\text { Chemicals OPEX } \\
\text { (M\$s/Yr 5) }\end{array}$ & 0 & 19.52 & 6.26 & 0 & 19.52 & 5.83 & 5.83 \\
\hline $\begin{array}{l}\text { Extraction } \\
\text { Throughput } \\
\text { Capacity (L/Hr) }\end{array}$ & 394,300 & 394,300 & 394,300 & 39,600 & 39,600 & 39,600 & 39,600 \\
\hline $\begin{array}{l}\text { Extraction } \\
\text { Capital Cost } \\
\text { (M\$s/Unit) }\end{array}$ & 23.57 & 23.57 & 23.57 & 10.20 & 10.20 & 10.20 & 10.20 \\
\hline $\begin{array}{l}\text { Number of } \\
\text { Extraction Units }\end{array}$ & 1 & 1 & 1 & 7 & 21 & 3 & 8 \\
\hline $\begin{array}{l}\text { Total Extraction } \\
\text { Capital Cost } \\
\text { (M\$s) }\end{array}$ & 23.57 & 23.57 & 23.57 & 71.42 & 214.27 & 30.61 & 81.63 \\
\hline $\begin{array}{l}\text { Extraction } \\
\text { Chemicals OPEX } \\
\text { (M\$s/Yr 5) }\end{array}$ & 14.1 & 14.1 & 14.1 & 0 & 0 & 0 & 0 \\
\hline $\begin{array}{l}\text { Extraction } \\
\text { Chemicals } \\
\text { Startup Cost (\$) }\end{array}$ & 0 & 0 & 0 & 34.7 & 104.3 & 14.9 & 39.7 \\
\hline \multicolumn{8}{|l|}{ CAPEX (M\$s) } \\
\hline Land & 35.9 & 35.9 & 35.9 & 35.9 & 35.9 & 35.9 & 35.9 \\
\hline Construction & 6.7 & 6.7 & 158.98 & 6.7 & 6.7 & 158.98 & 158.98 \\
\hline Liner & 205.2 & 205.2 & 156.9 & 205.2 & 205.2 & 156.9 & 156.9 \\
\hline Paddlewheels & 138.6 & 138.6 & 0 & 138.6 & 138.6 & 0 & 0 \\
\hline Total CAPEX & $1,211.9$ & $1,001.8$ & $1,012.2$ & $1,259.8$ & 1059.8 & $1,109.3$ & $1,070.3$ \\
\hline \multicolumn{8}{|l|}{ OPEX (M\$s/Yr 5) } \\
\hline $\begin{array}{l}\text { Labor \& } \\
\text { Overhead }\end{array}$ & 4.9 & 4.9 & 6.3 & 5.0 & 5.2 & 6.4 & 6.5 \\
\hline Natural Gas & 418.7 & 418.7 & 419.0 & 4.0 & 9.0 & 5.1 & 10.9 \\
\hline Electricity & 64.2 & 64.0 & 61.1 & 64.7 & 95.1 & 61.6 & 92.8 \\
\hline Maintenance & 41.6 & 17.0 & 18.2 & 43.2 & 25.2 & 18.1 & 20.4 \\
\hline Insurance & 2.4 & 2.0 & 2.0 & 2.5 & 2.4 & 2.0 & 2.1 \\
\hline Interest & 263.7 & 246.5 & 253.9 & 133.8 & 291.7 & 100.2 & 102.2 \\
\hline $\begin{array}{l}\text { Total OPEX } \\
\text { Year } 5\end{array}$ & 820.1 & 798.7 & 792.6 & 263.4 & 467.0 & 211.2 & 261.1 \\
\hline
\end{tabular}


Table 5. Summary of results for scenarios 1-7.

\begin{tabular}{|c|c|c|c|c|c|c|c|}
\hline & $\begin{array}{l}\text { Scenario 1 } \\
\text { Centrifuge } \\
\text { Wet Solvent } \\
\text { Extraction }\end{array}$ & $\begin{array}{l}\text { Scenario } 2 \\
\text { EC } \\
\text { Harvesting } \\
\text { Wet Solvent } \\
\text { Extraction } \\
\end{array}$ & $\begin{array}{l}\text { Scenario } 3 \\
\text { EC with Wet } \\
\text { Solvent } \\
\text { Extraction \& } \\
\text { ARID }\end{array}$ & $\begin{array}{l}\text { Scenario } 4 \\
\text { Centrifuge } \\
\text { HTL-CHG } \\
\text { Extraction }\end{array}$ & $\begin{array}{l}\text { Scenario } 5 \\
\text { EC with } \\
\text { HTL-CHG } \\
\text { GMO } \\
\text { Algae } \\
\end{array}$ & $\begin{array}{l}\text { Scenario } 6 \\
\text { HTL-CHG } \\
\text { EC \& } \\
\text { ARID } \\
\text { Cultivation }\end{array}$ & $\begin{array}{l}\text { Scenario } 7 \\
\text { GMO, } \\
\text { ARID, EC, } \\
\text { HTL-CHG }\end{array}$ \\
\hline $\begin{array}{l}\text { Reduction in } \\
\text { CAPEX }\end{array}$ & $90 \%$ & $90 \%$ & $90 \%$ & $80 \%$ & $70 \%$ & $70 \%$ & $50 \%$ \\
\hline $\begin{array}{l}\text { Reduction in } \\
\text { OPEX }\end{array}$ & $90 \%$ & $90 \%$ & $90 \%$ & $90 \%$ & $80 \%$ & $80 \%$ & $50 \%$ \\
\hline $\begin{array}{l}\text { Probability of } \\
\text { Economic } \\
\text { Success } \\
(\text { P(Success)) }\end{array}$ & $0.0-0.0$ & $0.0-0.0$ & $0.0-0.0$ & $0.0-89 \%$ & $0.0-98 \%$ & $0.0-67 \%$ & $0.0-55 \%$ \\
\hline $\begin{array}{l}\text { Average Total } \\
\text { Cost \$/gal } \\
\end{array}$ & 16.42 & 13.17 & 8.02 & 3.39 & 2.12 & 3.13 & 2.84 \\
\hline $\begin{array}{l}\text { Lower } \\
\text { Confidence } \\
\text { Interval TC } \\
\text { \$/gal } \\
\end{array}$ & 13.48 & 10.64 & 6.19 & 2.95 & 1.82 & 2.75 & 2.53 \\
\hline $\begin{array}{l}\text { Upper } \\
\text { Confidence } \\
\text { Interval TC } \\
\text { \$/gal }\end{array}$ & 21.99 & 17.98 & 10.75 & 4.46 & 2.67 & 3.79 & 3.48 \\
\hline
\end{tabular}


Table 6. Average net present value and probability of economic success for scenario 7 assuming fractional reductions in CAPEX and OPEX (M\$s).

Average Total Cost per Ton of Biomass (\$/Ton) and per Gallon of Lipid (\$/Gallon)

\begin{tabular}{|c|c|c|c|c|c|c|c|c|c|c|}
\hline \multirow{2}{*}{\begin{tabular}{|l|} 
ARID \\
Fraction OPEX
\end{tabular}} & \multicolumn{10}{|c|}{ Fractional Reductions in the CAPEX } \\
\hline & 0 & 0.1 & 0.2 & 0.3 & 0.4 & 0.5 & 0.6 & 0.7 & 0.8 & 0.9 \\
\hline 0 & -1078 & -967 & -856 & -745 & -634 & -523 & -412 & -302 & -191 & -81 \\
\hline & $0 \%$ & $0 \%$ & $0 \%$ & $0 \%$ & $0 \%$ & $0 \%$ & $0 \%$ & $0 \%$ & $0 \%$ & 7\% \\
\hline 0.1 & -965 & -854 & -743 & -632 & -521 & -411 & -300 & -190 & -82 & 25 \\
\hline & $0 \%$ & $0 \%$ & $0 \%$ & $0 \%$ & $0 \%$ & $0 \%$ & $0 \%$ & $0 \%$ & $6 \%$ & $68 \%$ \\
\hline 0.2 & -851 & -741 & -630 & -519 & -409 & -299 & -190 & -83 & 22 & 119 \\
\hline & $0 \%$ & $0 \%$ & $0 \%$ & $0 \%$ & $0 \%$ & $0 \%$ & $0 \%$ & $5 \%$ & $67 \%$ & $100 \%$ \\
\hline 0.3 & -738 & -627 & -517 & -407 & -298 & -191 & -85 & 17 & 113 & 205 \\
\hline & $0 \%$ & $0 \%$ & $0 \%$ & $0 \%$ & $0 \%$ & $0 \%$ & $4 \%$ & $65 \%$ & $100 \%$ & $100 \%$ \\
\hline 0.4 & -625 & -515 & -406 & -298 & -192 & -89 & 11 & 105 & 195 & 285 \\
\hline & $0 \%$ & $0 \%$ & $0 \%$ & $0 \%$ & $0 \%$ & $3 \%$ & $61 \%$ & $100 \%$ & $100 \%$ & $100 \%$ \\
\hline 0.5 & -513 & -406 & -300 & -196 & -94 & 3 & 95 & 184 & 273 & 362 \\
\hline & $0 \%$ & $0 \%$ & $0 \%$ & $0 \%$ & $2 \%$ & $55 \%$ & $99 \%$ & $100 \%$ & $100 \%$ & $100 \%$ \\
\hline 0.6 & -407 & -303 & -201 & -102 & -6 & 84 & 173 & 261 & 349 & 437 \\
\hline & $0 \%$ & $0 \%$ & $0 \%$ & $1 \%$ & $45 \%$ & $99 \%$ & $100 \%$ & $100 \%$ & $100 \%$ & $100 \%$ \\
\hline 0.7 & -307 & -207 & -111 & -17 & 73 & 161 & 249 & 336 & 424 & 511 \\
\hline & $0 \%$ & $0 \%$ & $1 \%$ & $33 \%$ & $98 \%$ & $100 \%$ & $100 \%$ & $100 \%$ & $100 \%$ & $100 \%$ \\
\hline 0.8 & -216 & -121 & -29 & 61 & 149 & 236 & 323 & 410 & 497 & 584 \\
\hline & $0 \%$ & $0 \%$ & $23 \%$ & $95 \%$ & $100 \%$ & $100 \%$ & $100 \%$ & $100 \%$ & $100 \%$ & $100 \%$ \\
\hline 0.9 & -133 & -41 & 48 & 135 & 222 & 308 & 395 & 481 & 568 & 654 \\
\hline & $0 \%$ & $13 \%$ & $90 \%$ & $100 \%$ & $100 \%$ & $100 \%$ & $100 \%$ & $100 \%$ & $100 \%$ & $100 \%$ \\
\hline
\end{tabular}


Table 7. Total cost of production for algae crude oil and biomass for scenario 7 assuming alternative fractional reductions in CAPEX and OPEX.

Average Total Cost per Ton of Biomass (\$/Ton) and per Gallon of Lipid (\$/Gallon)

\begin{tabular}{|c|c|c|c|c|c|c|c|c|c|c|}
\hline \multirow{2}{*}{\begin{tabular}{|l|} 
ARID \\
Fraction OPEX
\end{tabular}} & \multicolumn{10}{|c|}{ Fractional Reductions in the CAPEX } \\
\hline & 0 & 0.1 & 0.2 & 0.3 & 0.4 & 0.5 & 0.6 & 0.7 & 0.8 & 0.9 \\
\hline 0 & 1,033 & 963 & 894 & 825 & 756 & 688 & 620 & 553 & 486 & 420 \\
\hline & 7.40 & 6.90 & 6.40 & 5.90 & 5.40 & 4.90 & 4.50 & 4.00 & 3.50 & 3.00 \\
\hline 0.1 & 963 & 895 & 826 & 758 & 691 & 624 & 557 & 491 & 426 & 361 \\
\hline & 6.90 & 6.40 & 5.90 & 5.50 & 5.00 & 4.50 & 4.00 & 3.50 & 3.10 & 2.60 \\
\hline 0.2 & 896 & 828 & 761 & 694 & 628 & 563 & 498 & 433 & 368 & 305 \\
\hline & 6.40 & 6.00 & 5.50 & 5.00 & 4.50 & 4.00 & 3.60 & 3.10 & 2.60 & 2.20 \\
\hline 0.3 & 831 & 765 & 700 & 634 & 569 & 505 & 440 & 376 & 314 & 256 \\
\hline & 6.00 & 5.50 & 5.00 & 4.60 & 4.10 & 3.60 & 3.20 & 2.70 & 2.30 & 1.80 \\
\hline 0.4 & 771 & 705 & 641 & 576 & 512 & 447 & 385 & 325 & 270 & 216 \\
\hline & 5.50 & 5.10 & 4.60 & 4.10 & 3.70 & 3.20 & 2.80 & 2.30 & 1.90 & 1.60 \\
\hline 0.5 & 712 & 647 & 583 & 519 & 455 & 395 & 338 & 284 & 230 & 176 \\
\hline & 5.10 & 4.70 & 4.20 & 3.70 & 3.30 & 2.80 & 2.40 & 2.00 & 1.70 & 1.30 \\
\hline 0.6 & 654 & 590 & 526 & 464 & 407 & 352 & 298 & 244 & 191 & 137 \\
\hline & 4.70 & 4.20 & 3.80 & 3.30 & 2.90 & 2.50 & 2.10 & 1.80 & 1.40 & 1.00 \\
\hline 0.7 & 597 & 535 & 475 & 420 & 366 & 312 & 259 & 205 & 151 & 98 \\
\hline & 4.30 & 3.80 & 3.40 & 3.00 & 2.60 & 2.20 & 1.90 & 1.50 & 1.10 & 0.70 \\
\hline 0.8 & 545 & 488 & 434 & 380 & 326 & 273 & 219 & 165 & 112 & 58 \\
\hline & 3.90 & 3.50 & 3.10 & 2.70 & 2.30 & 2.00 & 1.60 & 1.20 & 0.80 & 0.40 \\
\hline 0.9 & 501 & 447 & 394 & 340 & 287 & 233 & 179 & 126 & 74 & 35 \\
\hline & 3.60 & 3.20 & 2.80 & 2.40 & 2.10 & 1.70 & 1.30 & 0.90 & 0.70 & 0.60 \\
\hline
\end{tabular}




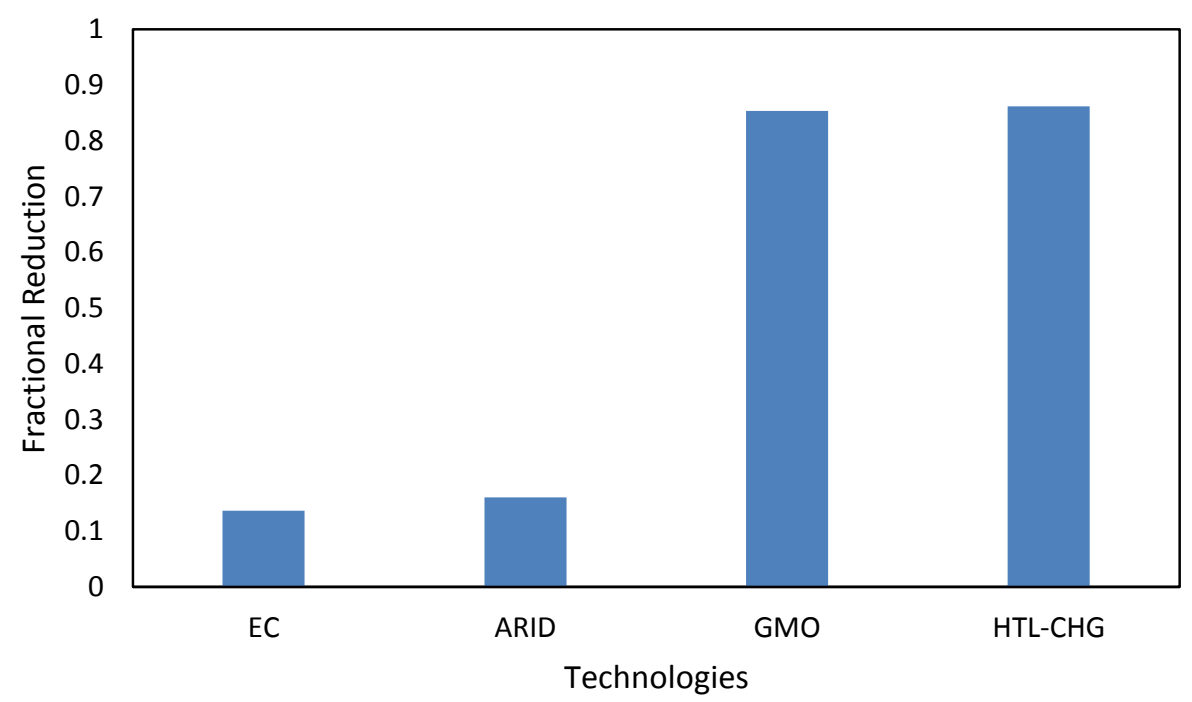

Figure 1. Fractional reductions in total costs of production for algae crude oil relative to the base scenario. 


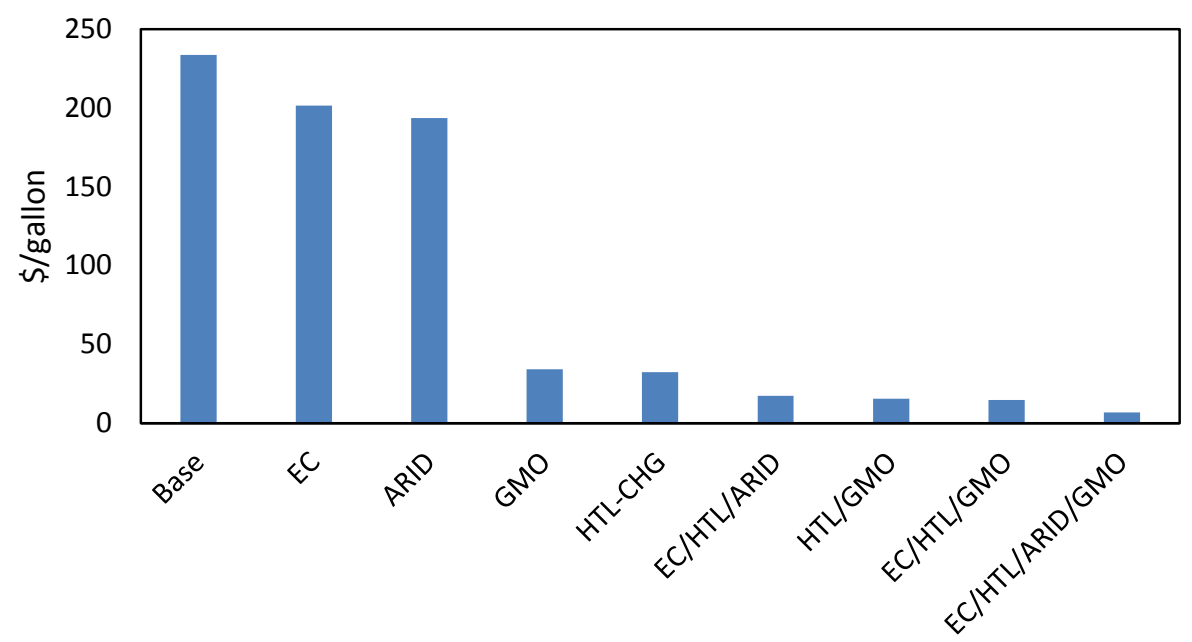

Technologies

Figure 2. Total economic plus financial costs of production for algae crude oil, for preNAABB technology, and for alternative technologies developed by NAABB (\$/gallon). For example, the EC cost of production is the scenario for which the centrifuge (base technology) is replaced with EC. In the EC/HTL/GMO scenario, the three listed technologies have replaced their three counterpart technologies in the baseline scenario. Integration of technologies allows for the savings of individual technologies to be combined, resulting in an even lower cost of production. 


\section{Appendix: Summary of Input Values for the Analysis.}

\section{$>\quad$ Financial Assumptions}

- CAPEX Debt interest rate $8 \%$

- CAPEX Loan Length 10 years

- Fraction of Cost Financed $60 \%$

- $\quad$ Fraction of Machinery Replacements Financed $\quad 80 \%$

- $\quad$ Years for Machinery Replacement Loans 5 years

- $\quad$ Interest Rate for Machinery Replacement Loans $\quad 8 \%$

$>\quad$ Cultivation Assumptions

- $\quad$ Farm Size (hectares) $\quad 4,850$ ha

Open Pond

- Water depth (cm) 30

- $\quad$ Raceway Area (hectares) 4 ha

- $\quad$ Generic Algal Strain Growth Rate $\left(\mathrm{g} / \mathrm{m}^{2} / \mathrm{d}\right)$

- $\quad$ GMO Algal Strain Growth Rate $\left(\mathrm{g} / \mathrm{m}^{2} / \mathrm{d}\right) \quad 19.4$

ARID

$\begin{array}{ll}-\quad \text { Average water depth }(\mathrm{cm}) & 10\end{array}$

- $\quad$ Raceway Area (hectares) $\quad 0.5$ ha

- $\quad$ Generic Algal Strain Growth Rate $\left(\mathrm{g} / \mathrm{m}^{2} / \mathrm{d}\right) \quad 9.3$

- $\quad$ GMO Algal Strain Growth Rate $\left(\mathrm{g} / \mathrm{m}^{2} / \mathrm{d}\right) \quad 23.2$ 


\section{$>\quad$ Harvesting Assumptions}

\section{Centrifugation}

- $\quad$ Throughput $\left(\mathrm{L} \mathrm{hour}^{-1}\right)$

- $\quad$ Number of Centrifuge Units

- $\quad$ Capital Cost per Unit (\$s)

- $\quad$ Harvest (hour day ${ }^{-1}$ )

- $\quad$ Effective recovery

- $\quad$ Percent solids of output

- $\quad$ Life of machine

- $\quad$ Maintenance cost

- $\quad$ Electricity

\section{Electrocoagulation}

- $\quad$ Throughput $\left(\right.$ L hour $\left.^{-1}\right)$

- $\quad$ Harvest (hour day ${ }^{-1}$ )

- $\quad$ Number of Electrocoagulation Units

- $\quad$ Capital Cost per Unit (\$s)

- $\quad$ Effective recovery

- $\quad$ Percent solids of output

- $\quad$ Life of machine

- Maintenance cost

- $\quad$ Electricity

- $\quad$ Plate Life Replacement Cost
113,560

2,231

$\$ 275,000$

16 hours

$90 \%$

$10 \%$

7 years

$3.6 \%$ of total CAPEX per yr.

$74 \mathrm{kwh} \mathrm{ton}^{-1}$

16 hours

Open Pond, 620; ARID, 185

$\$ 650,000$

$98 \%$

$8 \%$

7 years

$\$ 4,000$ per unit per yr.

$26 \mathrm{kwh} \mathrm{ton}^{-1}$

$\$ 0.04$ per thousand Liters processed 


\section{Extraction Assumptions}

Wet Solvent Extraction

- $\quad$ Throughput $\left(\right.$ L hour $\left.^{-1}\right)$

394,314

- Input percent solids $\quad 8 \%$

- Harvest (hour day ${ }^{-1}$ ) 24 hours

- Number of Wet Solvent Extraction Units $\quad 1$

- $\quad$ Capital Cost per Unit (\$s) \$23,566,667

- $\quad$ Effective extraction $90 \%$

- Life of machine $\quad 25$ years

- Maintenance cost $\quad 5 \%$ of total CAPEX per yr.

- $\quad$ Electricity (kwh ton ${ }^{-1}$ of algae) $\quad 63.40$

- $\quad$ Natural Gas (MMBtu/Hr of Operation) $\quad 1,860$

- $\quad$ Solvent required at startup (Tons) $\quad 30,000$

- Makeup solvent required per harvest (\%) $\quad 0.5 \%$

\section{HTL-CHG}

- $\quad$ Throughput $\left(\mathrm{L} \mathrm{day}^{-1}\right)$

950,000

- $\quad$ Harvest (hour day ${ }^{-1}$ )

24 hours

- $\quad$ Number of HTL-CHG Units

Scenario 4, 7 units; Scenario 5, 21

units; Scenario 6, 3 units; Scenario 7, 8 units

- $\quad$ Capital Cost per Unit (\$s)

$10,203,472$

- $\quad$ Catalyst Load Cost per Unit (\$s)

$4,967,906$ 
- $\quad$ Life of machine

- $\quad$ Maintenance cost

- $\quad$ Electricity (as \% system crude oil output)

- $\quad$ Electricity (as \$ system methane output)

- $\quad$ Natural Gas (as \% system crude oil output)

- $\quad$ Natural Gas (as \% system methane output)

- $\quad$ Slurry preparation cost (\$/ton)
20 years

$3.6 \%$ of total CAPEX per yr.

$4 \%$

$3 \%$

$6 \%$

$7 \%$

$\$ 0.50$

\section{OPEX Assumptions}

$\mathrm{CO}_{2}$

- $\quad$ Tons of $\mathrm{CO}_{2}$ Required $\mathrm{Ton}^{-1}$ of Biomass

- $\quad$ Efficiency of $\mathrm{CO}_{2}$

$85 \%$

- $\quad$ Contract cost $\left(\$\right.$ ton $\left.^{-1}\right)$

$\$ 20$

Nutrients $\left(\$\right.$ year $\left.^{-1}\right)$

$\$ 4,800,000$

Utilities $\left(\$\right.$ year $^{-1}$ )

Open Pond

$\$ 104,125$

ARID

$\$ 132,207$

Labor

- $\quad$ Non-Harvesting \& Extraction Labor

$\$ 4,269,109$

- $\quad$ ARID Labor

$\$ 1,151,383$ 
Non harvesting and extraction maintenance costs $\left(\$\right.$ year $\left.^{-1}\right)$

Open Pond

ARID

Workman's Compensation/Unemployment Tax Rate

Insurance
$\$ 9,995,663$

$\$ 12,691,884$

$8 \%$

$\$ 0.00186 \times$ sum of CAPEX costs 